\title{
Desain dan Implementasi Data Logger untuk Pengukuran Daya Keluaran Panel Surya dan Iradiasi Matahari
}

\author{
APIP PUDIN, IGNATIUS RIYADI MARDIYANTO
}

\author{
Jurusan Teknik Konversi Energi, Politeknik Negeri Bandung \\ Email: apipp055@gmail.com
}

Received 29 November 2019 | Revised 1 Februari 2020 | Accepted 2 April 2020

\begin{abstract}
ABSTRAK
Informasi mengenai daya keluaran panel surya dan intensitas radiasi matahari diperlukan dalam sistem PLTS guna mengetahui karakteristik potensi daya yang dibangkitkan panel dan estimasi besarnya beban yang terpasang. Dalam penelitian ini, telah dirancang perangkat data logger berbasis Arduino Uno dengan media penyimpan data berupa kartu MicroSD dan format data MS Excel. Parameter daya diperoleh menggunakan modul sensor tegangan dengan prinsip pembagi tegangan dan sensor arus dengan resistor shunt. Intensitas radiasi diperoleh dari sensor Solar Power Meter menggunakan interface kabel RS232 to TTL. Hasil menunjukan nilai rata-rata error tegangan sebesar $36 \mathrm{mV}$ atau inakurasi 0,41\% untuk rentang pengukuran dari 0,7 V sampai $24 \mathrm{~V}$, sedangkan rata-rata error arus sebesar $10 \mathrm{~mA}$ atau inakurasi 0,42\% untuk pengukuran dari 0,3 A sampai 7,5 A. Nilai inakurasi ini masih dibawah nilai rata-rata alat ukur standar yang ada di pasaran sekitar 1\%, sehingga hasil rancangan ini bisa digunakan untuk keperluan pengukuran.
\end{abstract}

Kata kunci: tegangan, arus, daya, iradiasi matahari, Arduino

\begin{abstract}
Information about the output power of solar panels and the intensity of solar radiation are needed in the PV system to determine the characteristics of the power generated by the panel and the estimated amount of installed load. In this research, an Arduino-based data logger has been designed with a MicroSD card data storage media and a MS Excel data format. Power parameters are obtained using a voltage sensor module with the principle of a voltage divider and a current sensor with a shunt resistor. The radiation intensity is obtained from the Solar Power Meter sensor using a RS232 to TTL cable interface. The results show the average of voltage error is $36 \mathrm{mV}$ or inaccuracy is $0.41 \%$ for the measurement range from $0.7 \mathrm{~V}$ to $24 \mathrm{~V}$, while the average of current error is $10 \mathrm{~mA}$ or inaccuracy is $0.42 \%$ for the measurement from $0.3 \mathrm{~A}$ to $7.5 \mathrm{~A}$. This inaccuracy value is still below the average value of standard measurement tools on the market about $1 \%$, so the results of this design can be used for the purpose of measurements.
\end{abstract}

Keywords: voltage, current, power, solar irradiation, Arduino 
Desain dan Implementasi Data Logger untuk Pengukuran Daya Keluaran Panel Surya dan Iradiasi Matahari

\section{PENDAHULUAN}

Pencatatan data (data logging) merupakan aspek penting dalam sistem pengukuran dan instrumentasi modern. Data Logger menyediakan fungsi pengukuran dan pencatatan data dengan menggunakan transduser, komputer dan sensor (Singh, dkk, 2019). Data logger sering digunakan untuk menyimpan informasi dalam waktu yang lama dan mengumpulkan data yang berhubungan dengan parameter listrik dan meteorologi (Mahzan, dkk, 2017). Dalam sistem Pembangkit Listrik Tenaga Surya (PLTS), energi listrik yang dibangkitkan oleh panel surya (PV) dipengaruhi oleh kondisi lingkungan seperti temperatur, radiasi matahari, arah dan spektrum sinar matahari (Singh, 2013). Pengukuran sistem PLTS bekerja selama periode waktu yang lama dan menghasilkan banyak data, sehingga penggunaan perangkat konvensional seperti multimeter tidak akan efektif untuk mendapatkan data yang benar apalagi ketika terjadi perubahan cepat dari kondisi lingkungan (Sugiartha, dkk, 2018). Untuk itu diperlukan suatu perangkat digital berupa data logger yang bisa bekerja secara otomatis dan bisa menjawab kekurangan-kekurangan yang ada pada penggunaan perangkat konvensional. Sebagian besar alat ukur ini sudah tersedia di pasaran dengan berbagai macam fitur, harga dan spesifikasinya. Tetapi pada kondisi tertentu diperlukan suatu sistem perangkat akuisisi tersendiri yang sesuai dengan kebutuhan objek pengukuran seperti rentang nilai pengukuran, akurasi dan aksesibilitas data (Raj, 2018). Selain itu, diperlukan data terukur yang bisa terintegrasi pada sistem cerdas yang tidak bisa dilakukan oleh perangkat konvensional, misalnya akuisisi data secara real time atau data bisa disimpan dalam data logger serta bisa dikirim ke perangkat lain baik melalui kabel maupun tanpa kabel seperti pada Internet of Thing (IoT).

Berbagai penelitian yang berhubungan dengan sistem akuisisi data parameter panel surya telah diusulkan dalam literatur, misalnya penelitian tentang akuisisi data parameter PV dalam bentuk perangkat virtual berbiaya murah menggunakan program Excel dan Arduino, serta menampilkan data dalam bentuk kurva arus-tegangan (I-V) dan kurva daya-tegangan (P-V) (El Hammoumi, dkk, 2018). Sugiartha (Sugiartha, dkk, 2018) membuat sistem akuisisi data (DAQ) berbasis Arduino untuk menyimpan data tegangan, arus, temperatur, dan kelembaban dalam SD Card dan menampilkannya dalam bentuk kurva grafik parameterparameter tersebut terhadap waktu. Teli (Teli, dkk, 2015) mengembangkan data logger berbasis Arduino secara real time untuk pengukuran indoor dan outdoor. Penggunaan perangkat lunak komersial dalam sistem monitoring PV secara real timejuga digunakan seperti yang dilakukan oleh Touati (Touati, dkk, 2016) yang menggunakan LabView dalam penelitiannya untuk monitoring pengaruh paparan debu terhadap keluaran daya maksimum dari modul PV. Suryavanshi (Suryavanshi, dkk, 2016) mengembangkan sistem pemantauan online dan simulasi kontrol beban panel surya berbasis mikrokontroler AVR Atmega 16 menggunakan Matlab. Mandal (Mandal, dkk, 2017) mengembangkan sistem akuisisi data berbasis Labview untuk monitoring tegangan PV dengan penjejak arah sinar matahari. Selanjutnya, Painjane (Painjane, dkk, 2014) telah merancang detektor dan data logger untuk level insolasi matahari menggunakan mikrokontroler dan sensor fotodioda, dimana keluarannya sudah berupa parameter level insolasi dalam satuan watt per meter persegi. Hanya saja dari penelitian-penelitian yang telah dipaparkan di atas belum dibahas mengenai sistem akuisisi yang menghubungkan daya keluaran panel surya dengan suatu parameter yang paling penting dan utama, yaitu intensitas radiasi matahari. Informasi ini diperlukan dalam sistem PLTS guna mengetahui karakteristik potensi daya yang dibangkitkan panel dan estimasi besarnya beban yang terpasang. Oleh karena itu, pada penelitian ini akan dibahas perancangan perangkat sistem akuisisi daya keluaran panel surya dan intensitas radiasi matahari secara bersamaan atau paralel berbasis mikrokontroler Arduino Uno. Perangkat akuisisi dirancang dalam bentuk data logger dengan menggunakan media penyimpanan data 
berupa kartu MicroSD dan format data MS Excel. Rancangan sensor tegangan dan arus disesuaikan untuk implementasi pengukuran daya panel surya dengan tegangan $24 \mathrm{~V}$ dan arus di bawah 10 A, sedangkan intensitas radiasi diperoleh dari Solar Power Meter SPM 1116SD melalui komunikasi kabel Serial to TTL.

\section{METODE PENELITIAN}

\subsection{Karakterisasi Sensor Tegangan dan Arus}

Sistem akuisisi daya keluaran panel surya memerlukan dua parameter yaitu tegangan (V) dan arus (I). Daya (P) yang diterima beban listrik DC merupakan perkalian antara tegangan dan arus yang melewatinya, dirumuskan dengan Persamaan (1).

$$
P=V \times I \quad \text { (satuan Watt) }
$$

Karena keluaran dari panel surya masih berupa sinyal analog maka perlu dirancang suatu pengkondisi sinyal yang tepat agar kedua parameter itu bisa diolah oleh mikrokontroler yang bekerja secara digital. Dalam penelitian ini daya keluaran panel surya diperoleh menggunakan modul sensor tegangan dengan prinsip rangkaian pembagi tegangan dan modul sensor arus dengan resistor shunt seperti diperlihatkan pada Gambar 1 (Raj, 2018).

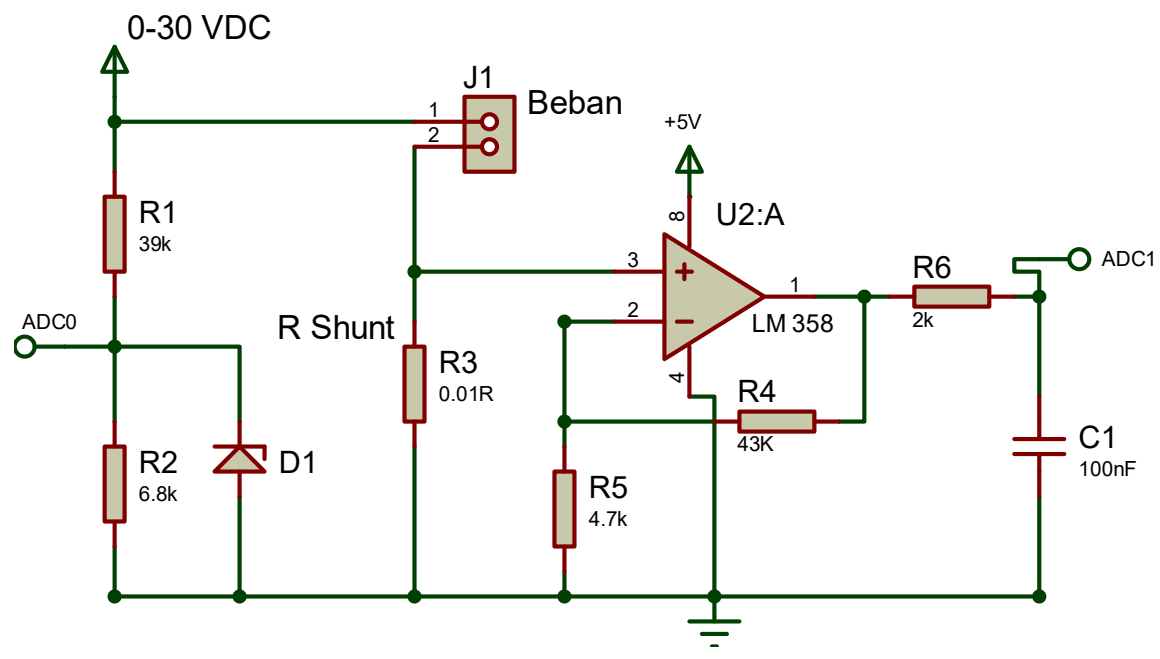

\section{Gambar 1. Rangkaian Sensor Arus dan Tegangan}

Modul sensor tegangan dan arus dirancang dengan input tegangan maksimum $30 \mathrm{~V}$ dan arus maksimum $8 \mathrm{~A}$. Nilai keluaran sensor diatur supaya sinyal tegangan tidak lebih dari $5 \mathrm{~V}$ sebagai masukan untuk ADC mikrokontroler. Spesifikasi komponen resistor disesuaikan dengan fungsinya untuk kebutuhan alat ukur yang memerlukan tingkat kepresisian yang tinggi, yaitu nilai tahanan resistor yang stabil dengan toleransi $1 \%$ dan rating daya yang sesuai (Knight, 2016). 


\subsection{Akuisisi Data Sensor Radiasi}

Intensitas radiasi matahari diperoleh dari sensor Solar Power Meter SPM1116SD (Gambar 2).

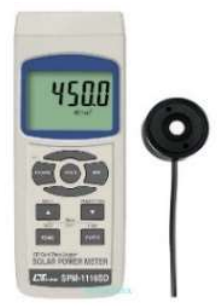

\section{Gambar 2. Solar Power Meter SPM1116SD}

Radiasi matahari diterima dan dibaca oleh sensor Solar Power Meter dalam bentuk sinyal serial dan terbaca di software serial Hterm berupa data ASCII, hexadesimal, desimal dan biner seperti diperlihatkan pada Gambar 3.

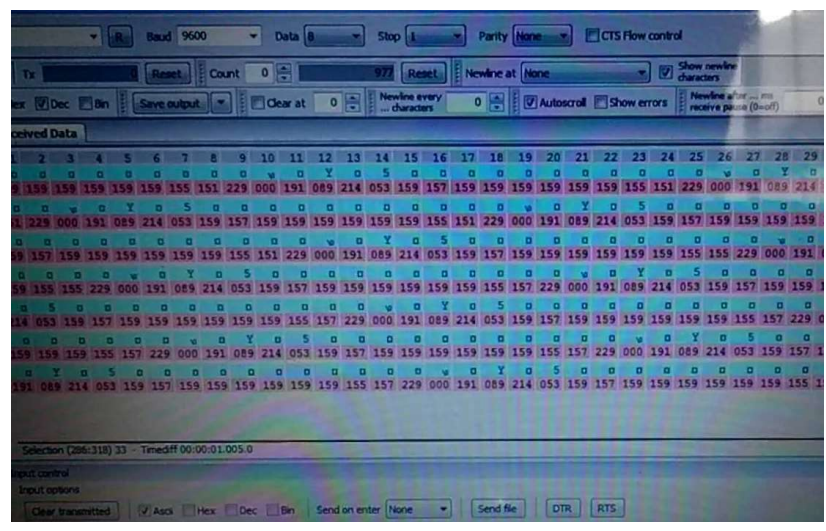

\section{Gambar 3. Data Serial Desimal di Hterm}

Sinyal desimal merupakan sinyal yang dapat dikonversi secara langsung karena dapat menentukan besaran nilai radiasinya. Tabel pembacaan nilai radiasi yang dihasilkan melalui Hterm adalah sebagai berikut:

Tabel 1. Pembacaan Nilai Serial Radiasi

\begin{tabular}{|c|c|c|}
\hline No & $\begin{array}{c}\text { Pembacaan } \\
\text { Serial }\end{array}$ & $\begin{array}{c}\text { Pembacaan } \\
\text { Nilai Radiasi }\end{array}$ \\
\hline 1 & 159 & 0 \\
\hline 2 & 157 & 1 \\
\hline 3 & 155 & 2 \\
\hline 4 & 153 & 3 \\
\hline 5 & 151 & 4 \\
\hline 6 & 149 & 5 \\
\hline 7 & 147 & 6 \\
\hline 8 & 145 & 7 \\
\hline 9 & 143 & 8 \\
\hline 10 & 141 & 9 \\
\hline
\end{tabular}


Nilai serial desimal tersebut dipasing dari setiap bit yang menunjukkan nilai radiasinya yaitu bit $10,11,12,13,14$. Pembacaan nilai radiasi menggunakan format $9600,8 \mathrm{~N}, 1$; yang mana format tersebut diperoleh dari datasheet sensor tersebut.

Data serial dikirim dan dibaca oleh mikrokontroler Arduino via interface kabel RS232 to TTL dan data desimal dikonversikan menjadi nilai iradiasi matahari menggunakan algoritma program pada Gambar 4.

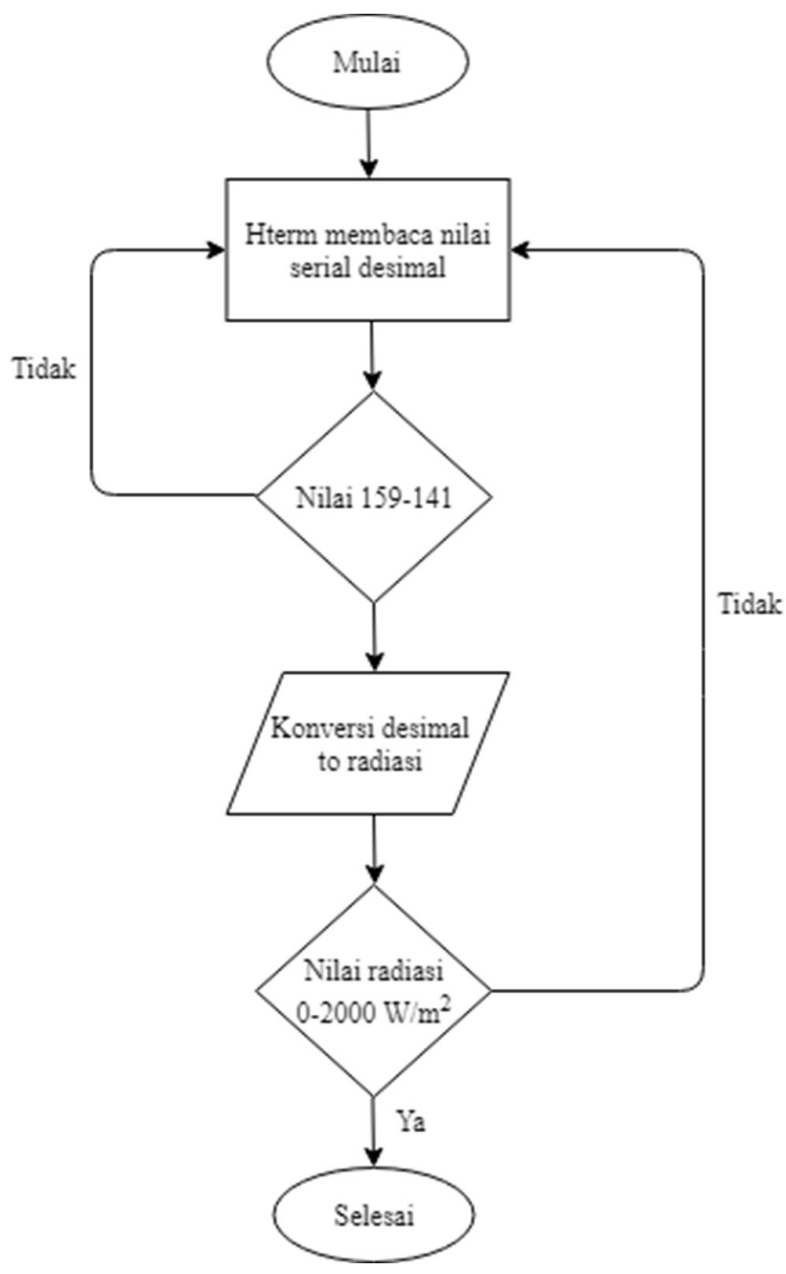

Gambar 4. Algoritma Pemrograman Pembacaan Sensor Radiasi Matahari

\subsection{Implementasi Pengukuran}

Perangkat data logger diimplementasikan untuk mengakuisisi daya keluaran panel surya dan iradiasi matahari secara bersamaan sehingga data yang terekam bisa diolah untuk menampilkan hubungan keduanya. Data terukur berupa parameter tegangan, arus dan iradiasi matahari yang disimpan dalam kartu MicroSD dengan komunikasi Serial Peripheral Interface (SPI) melalui pin MOSI dan MISO. Data juga bisa direkam menggunakan aplikasi MS Excel di komputer melalui aplikasi PLX-Daq serta ditampilkan di layar LCD melalui komunikasi I2C. Konstruksi alat data logger diperlihatkan pada Gambar 5. 


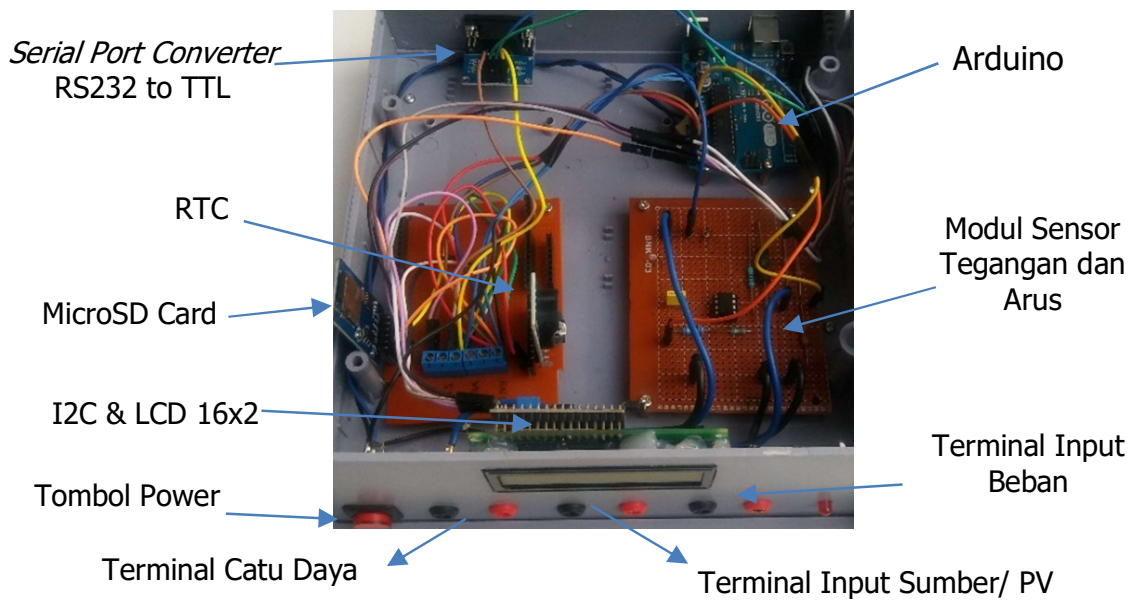

Gambar 5. Konstruksi Alat Data Logger

Panel surya yang digunakan pada pengujian menggunakan merk "bp solar" dengan kapasitas per modul sebesar $50 \mathrm{Wp}$ (Voc 21,8 V; Isc 3,2 A) sebanyak 10 buah dan terpasang paralel. Sedangkan untuk sampel beban (resistif) menggunakan rheostat dengan tahanan sebesar 28 Ohm. Realisasi perangkat pengukuran diperlihatkan pada Gambar 6.

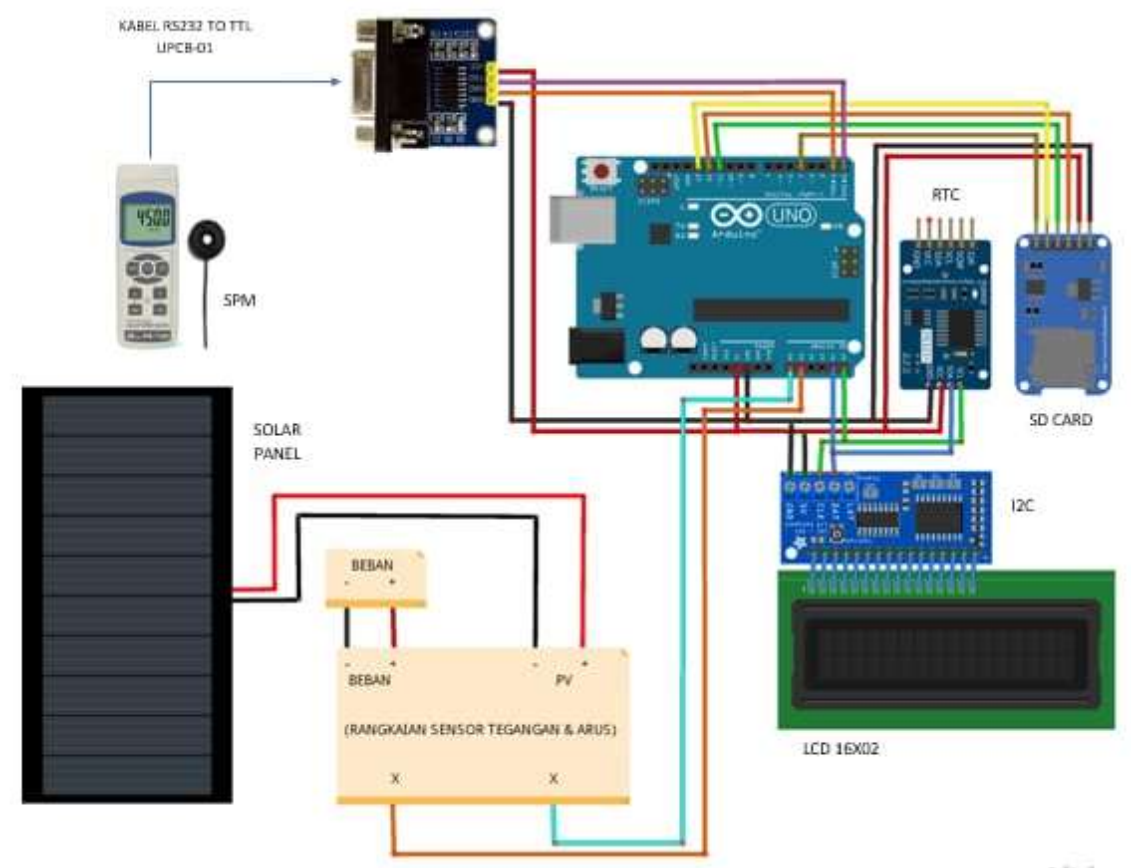

Gambar 6. Realisasi Perangkat Pengukuran

\section{HASIL DAN PEMBAHASAN}

\subsection{Pengujian Sensor Tegangan}

Berdasarkan pengujian nilai tegangan sensor dan nilai ADC yang terukur Arduino, didapat data hasil pengukuran seperti tampak pada Tabel 2. Hasil pengukuran menunjukkan adanya 
linearitas antara tegangan sumber dengan nilai ADC seperti diperlihatkan pada Gambar 7. Dari hubungan linier ini diperoleh persamaan linier untuk mendapatkan nilai tegangan yang akan terbaca di monitor Arduino. Akurasi hasil pengukuran menunjukkan nilai rata-rata error tegangan sebesar $36 \mathrm{mV}$ atau inakurasi sebesar $0,41 \%$ untuk rentang pengukuran dari $0,7 \mathrm{~V}$ sampai $24 \mathrm{~V}$. Nilai inakurasi ini masih di bawah nilai beberapa alat ukur standar yang ada di pasaran pada rentang pengukuran yang sesuai, misalnya multimeter merk Fluke 115 dengan inakurasi pengukuran tegangan DC sebesar 0,5\% (Fluke Corp, 2009).

Tabel 2. Hasil Pengujian Sensor Tegangan

\begin{tabular}{|c|c|c|c|c|c|}
\hline No & ADC & V Sumber (V) & V Arduno (V) & Error (V) & Inakurasi \\
\hline 1 & 18 & 0,701 & 0,697 & 0,004 & $0,51 \%$ \\
\hline 2 & 44 & 1,529 & 1,532 & 0,003 & $0,20 \%$ \\
\hline 3 & 91 & 3,012 & 3,041 & 0,029 & $0,95 \%$ \\
\hline 4 & 122 & 4,006 & 4,036 & 0,030 & $0,74 \%$ \\
\hline 5 & 153 & 5,053 & 5,031 & 0,022 & $0,44 \%$ \\
\hline 6 & 187 & 6,091 & 6,122 & 0,031 & $0,51 \%$ \\
\hline 7 & 248 & 8,070 & 8,080 & 0,010 & $0,13 \%$ \\
\hline 8 & 309 & 10,020 & 10,039 & 0,018 & $0,18 \%$ \\
\hline 9 & 375 & 12,080 & 12,157 & 0,077 & $0,64 \%$ \\
\hline 10 & 436 & 14,060 & 14,115 & 0,055 & $0,39 \%$ \\
\hline 11 & 498 & 16,060 & 16,105 & 0,045 & $0,28 \%$ \\
\hline 12 & 562 & 18,130 & 18,160 & 0,030 & $0,16 \%$ \\
\hline 13 & 622 & 20,060 & 20,086 & 0,026 & $0,13 \%$ \\
\hline 14 & 743 & 24,090 & 23,970 & 0,120 & $0,50 \%$ \\
\hline \multicolumn{5}{|c|}{ Rata-rata } \\
\hline
\end{tabular}

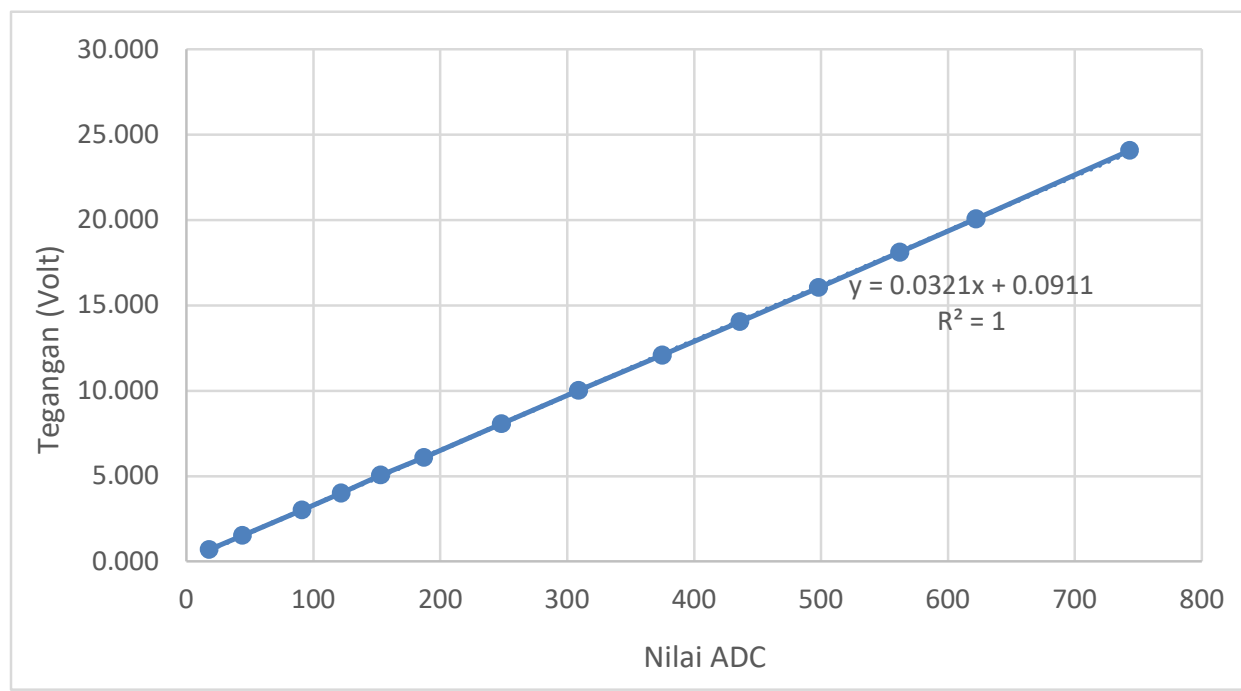

Gambar 7. Grafik Linearitas Tegangan Sumber dan ADC 
Desain dan Implementasi Data Logger untuk Pengukuran Daya Keluaran Panel Surya dan Iradiasi Matahari

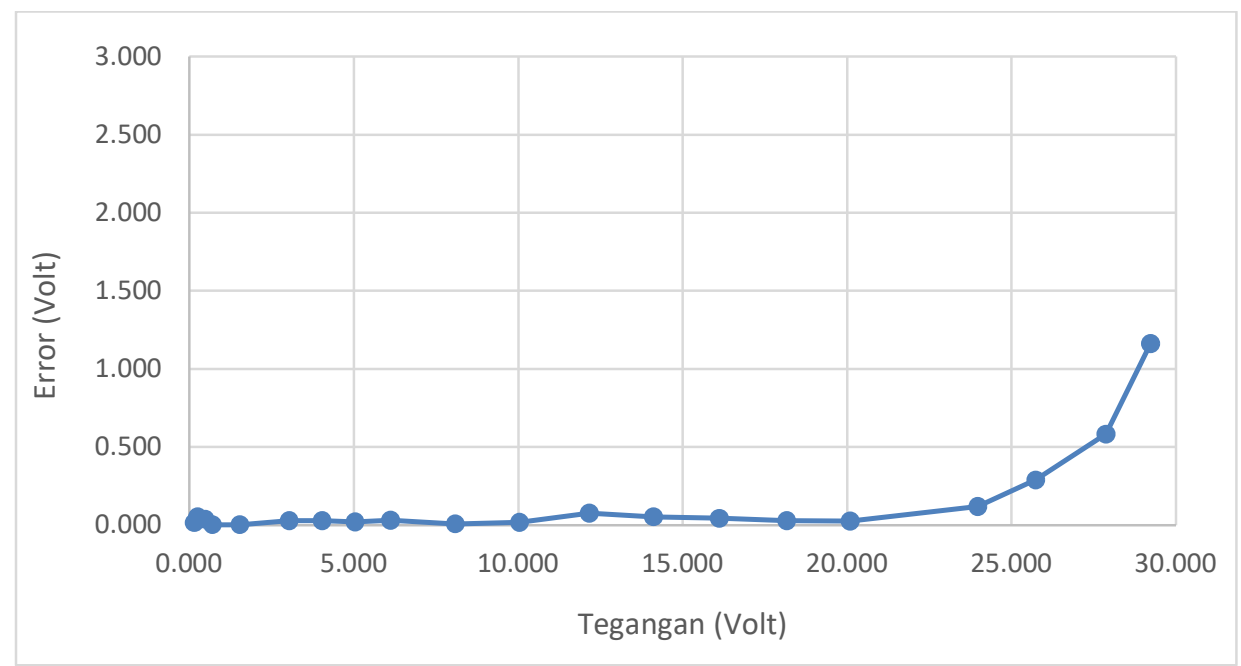

Gambar 8. Grafik Nilai ErrorTegangan

\subsection{Pengujian Sensor Arus}

Berdasarkan hasil pengujian nilai arus beban dan nilai ADC yang terukur Arduino didapat data hasil pengukuran seperti diperlihatkan pada Tabel 3. Hasil pengukuran menunjukkan adanya linearitas antara arus beban dengan nilai ADC seperti diperlihatkan pada Gambar 9. Dari hubungan linier ini diperoleh persamaan linier untuk mendapatkan nilai arus yang akan terbaca di monitor Arduino. Akurasi hasil pengukuran menunjukkan nilai rata-rata error arus sebesar $10 \mathrm{~mA}$ atau inakurasi sebesar 0,42\% untuk rentang pengukuran dari 0,3 A sampai 7,5 A. Nilai inakurasi ini juga masih di bawah nilai beberapa alat ukur standar yang ada di pasaran pada rentang pengukuran yang sesuai, misalnya multimeter merk Fluke 115 dengan inakurasi pengukuran arus DC sebesar 1,0\% (Fluke Corp, 2009).

Tabel 3. Hasil Pengujian Sensor Arus

\begin{tabular}{|c|c|c|c|c|c|}
\hline No & ADC & I Beban (A) & I Arduino (A) & Error (A) & Inakurasi \\
\hline 1 & 4 & 0,323 & 0,326 & 0,003 & $0,80 \%$ \\
\hline 2 & 23 & 0,508 & 0,510 & 0,002 & $0,37 \%$ \\
\hline 3 & 44 & 0,707 & 0,714 & 0,007 & $0,93 \%$ \\
\hline 4 & 75 & 1,008 & 1,014 & 0,006 & $0,62 \%$ \\
\hline 5 & 126 & 1,513 & 1,509 & 0,004 & $0,26 \%$ \\
\hline 6 & 178 & 2,001 & 2,013 & 0,012 & $0,62 \%$ \\
\hline 7 & 228 & 2,52 & 2,498 & 0,022 & $0,86 \%$ \\
\hline 8 & 293 & 3,137 & 3,129 & 0,008 & $0,26 \%$ \\
\hline 9 & 338 & 3,564 & 3,565 & 0,001 & $0,04 \%$ \\
\hline 10 & 381 & 4,005 & 3,983 & 0,023 & $0,56 \%$ \\
\hline 11 & 440 & 4,574 & 4,555 & 0,019 & $0,42 \%$ \\
\hline 12 & 498 & 5,12 & 5,117 & 0,003 & $0,05 \%$ \\
\hline 13 & 592 & 6,043 & 6,029 & 0,014 & $0,23 \%$ \\
\hline 14 & 669 & 6,76 & 6,776 & 0,016 & $0,24 \%$ \\
\hline 15 & 743 & 7,5 & 7,494 & 0,006 & $0,08 \%$ \\
\hline & \multicolumn{3}{|c|}{ Rata-rata } & $0,010 \mathrm{~A}$ & $0,42 \%$ \\
\hline
\end{tabular}




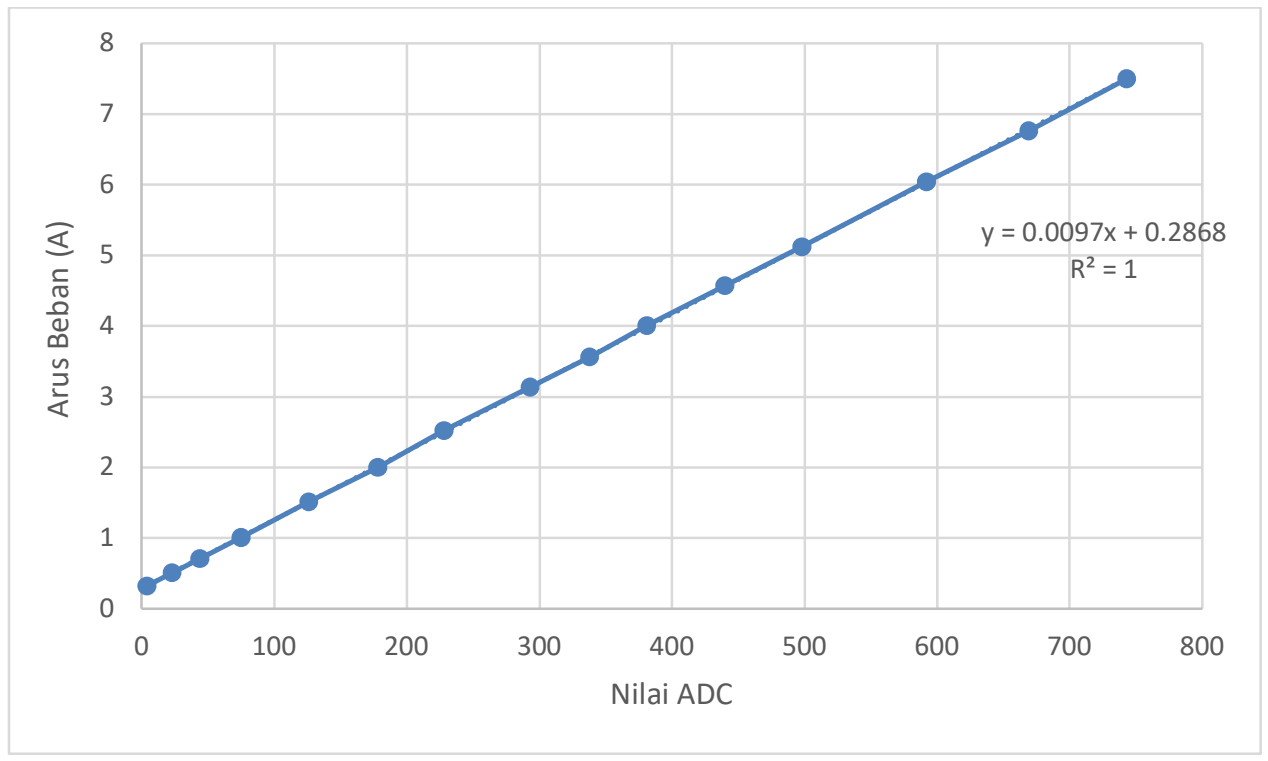

Gambar 9. Grafik Linearitas Arus Beban dan ADC

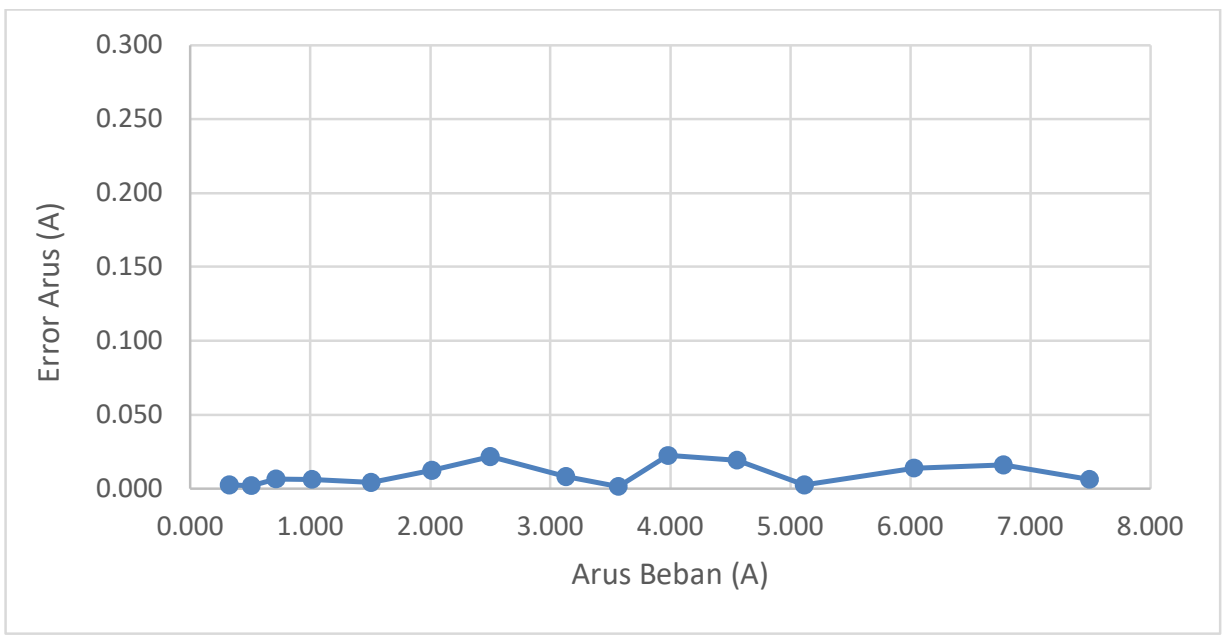

Gambar 10. Grafik Nilai Error Arus Beban

\subsection{Akuisisi Daya Panel Surya dan Intensitas Radiasi Matahari}

Pengujian dilakukan tanggal 21 Oktober 2019 selama 3 jam dari pukul 11.00 sampai 14.00 di Laboratorium Pembangkit Energi Terbarukan, Politeknik Negeri Bandung. Pengambilan sampel data dilakukan tiap 2 detik dan disimpan dalam data logger yang menampilkan parameter waktu (tanggal/bulan/tahun dan jam) tegangan, arus, daya dan iradiasi matahari. Selanjutnya data diolah dalam bentuk grafik untuk melihat hubungan nilai iradiasi dan daya keluaran panel surya terhadap waktu seperti diperlihatkan pada Gambar 11 dan Gambar 12. 
Desain dan Implementasi Data Logger untuk Pengukuran Daya Keluaran Panel Surya dan Iradiasi Matahari

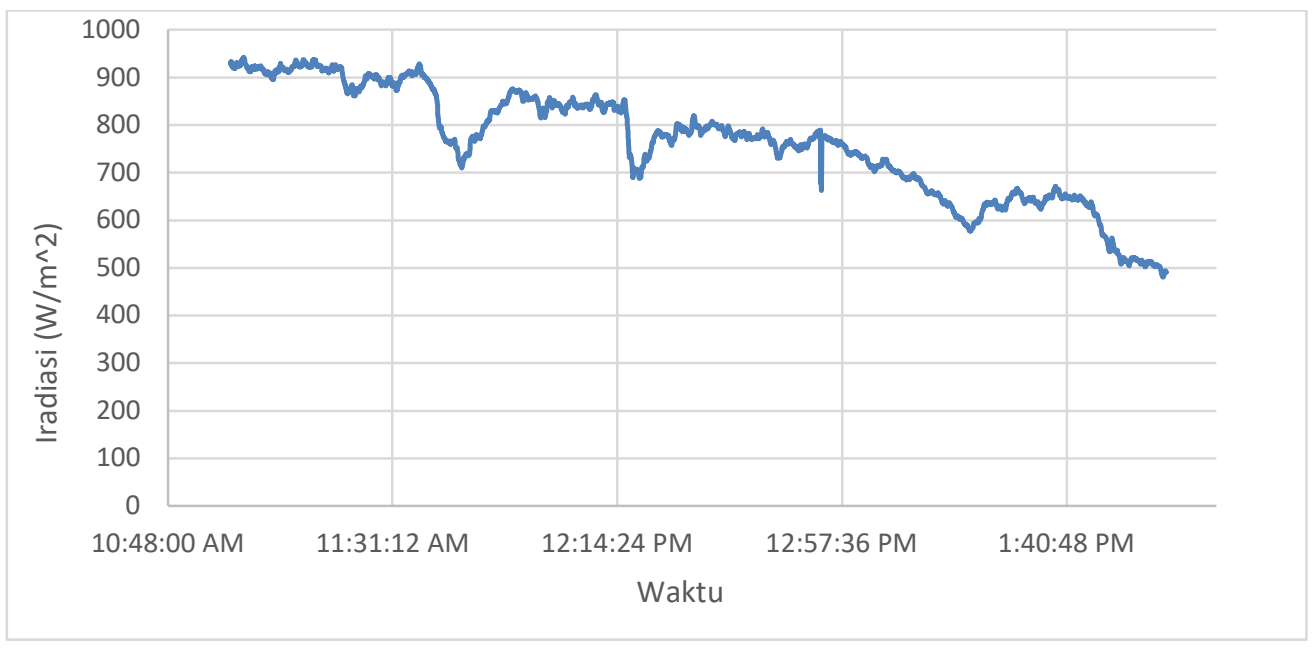

Gambar 11. Grafik Nilai Iradiasi Matahari terhadap Waktu

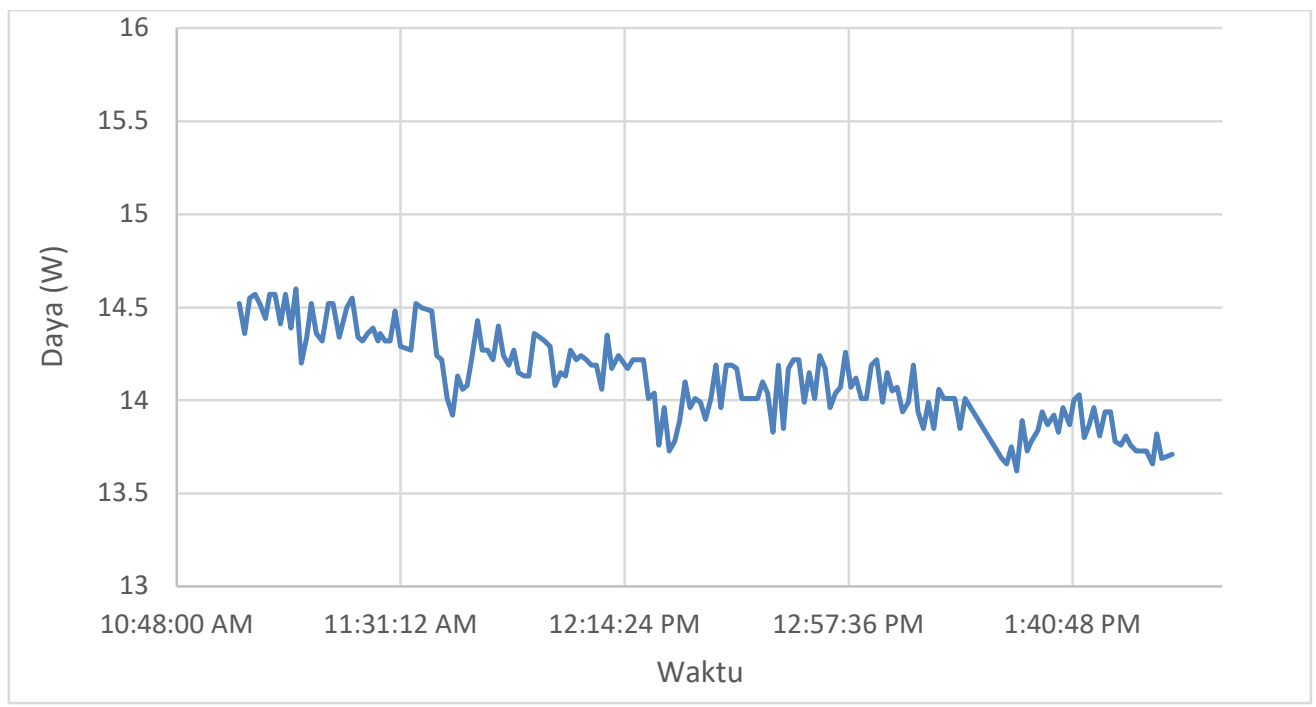

Gambar 12. Grafik Nilai Daya terhadap Waktu

Gambar 11 menunjukan grafik nilai iradiasi matahari per 2 detik berubah dari sekitar $930 \mathrm{~W} / \mathrm{m}^{2}$ di pukul pukul 11.00 menjadi sekitar $480 \mathrm{~W} / \mathrm{m}^{2}$ di pukul 14.00 dan Gambar 12 menunjukkan grafik nilai daya rata-rata yang disuplai ke beban (beban resistif $28 \mathrm{Ohm}$ ) per menit ikut berubah dari sekitar $15 \mathrm{~W}$ sampai 13,5 W. Profil daya dan iradisi ini bermamfaat untuk untuk mengestimasi secara akurat antara besarnya beban yang terpasang dan daya yang disuplai panel surya.

\section{KESIMPULAN}

Desain data logger telah berhasil dibuat dan diimplementasikan untuk pengukuran daya keluaran panel surya dan intensitas radiasi matahari. Spesifikasi alat ukur yang diperoleh mempunyai nilai rata-rata error tegangan sebesar $36 \mathrm{mV}$ atau inakurasi $0,41 \%$ untuk rentang pengukuran dari $0,7 \mathrm{~V}$ sampai $24 \mathrm{~V}$; dan nilai rata-rata errorarus sebesar $10 \mathrm{~mA}$ atau inakurasi $0,42 \%$ untuk rentang pengukuran dari 0,3 A sampai 7,5 A. Nilai inakurasi ini masih di bawah 
nilai rata-rata alat ukur standar yang ada di pasaran sekitar $1 \%$, sehingga hasil rancangan ini bisa digunakan untuk keperluan pengukuran.

\section{UCAPAN TERIMA KASIH}

Penelitian ini didukung oleh DIPA POLBAN 2019 Skema Penelitian Pemula Nomor 348.3/PL1.R7/LT/2019. Penulis ingin mengucapkan terima kasih atas dukungan yang diberikan pada karya ini.

\section{DAFTAR RUJUKAN}

El Hammoumi, A., Motahhir, S., Chalh, A., El Ghzizal, A., \& Derouich, A. (2018). Low-cost virtual instrumentation of PV panel characteristics using Excel and Arduino in comparison with traditional instrumentation, Renewables.

Fluke Corp. (2009). Fluke 115 Multimeter Technical Data. USA.

Knight, D. (2016). Introduction to Current Shunt Monitors. Retrieved from https://www.digikey.com.

Mahzan, N. N., Omar,A. M. ,Rimon,L., Mohammad Noor, S.Z., Rosselan, M. Z. (2017). Design and Development of An Arduino Based Data Logger for Photovoltaic Monitoring System. International Journal of Simulation Systems, Science, and Technology, 1入41), 1-5.

Mandal, S., Singh, D. (2017). Real Time Data Acquisation of Solar Panel Using Arduino and Further Recording Voltage of The Solar Panel. International Journal of Instrumentation and Control Systems (IJICS), ス3).

Painjane, P., Nangare, R., Pardeshi, A. (2014). Design of Solar Insolation Level Detector. International Journal of Current Engineering and Technology, 4(3).

Raj, A. (2018). Arduino Wattmeter: Measure Voltage, Current and Power Consumption. Retrieved from https://circuitdigest.com.

Singh, G. (2013). Solar power generation by PV (photovoltaic) technology: A review. Energy, $53,1-13$.

Singh, T., Thakur, R. (2019). Design and Development of PV Solar Panel Data Logger. International Journal of Computer Sciences and Engineering (IJCSE), 7.

Sugiartha, N., Sugina, I.M., Agus, I.D.W. (2018). Development of an Arduino-based Data Acquisition Device for Monitoring Solar PV System Parameters. International Conference on Science and Technology (ICST).

Suryavanshi, S., Tiwari, S., \& Kumar, S. (2017). Online Monitoring and Controlling of The PV Generated Solar Power Through AVR Microcontroller ATmega16. In 2nd International Conference for Convergence in Technology (I2CT), (pp. 169-173). 
Desain dan Implementasi Data Logger untuk Pengukuran Daya Keluaran Panel Surya dan Iradiasi Matahari

Teli, S., Mani (2015). Smart Real Time Embedded Arduino Based Data Acquisition System. International Journal of Research in Engineering and Technology, 4, 258-262.

Touati, F., Al-Hitmi, M.A., Chowdury, N.A., Hamad, J.A., \& Gonzales, A.S.P. (2016). Investigation of solar PV Performance under Doha Weather using a Customized Measurement and Monitoring System. Renewable Energy. 89, 564-577. 